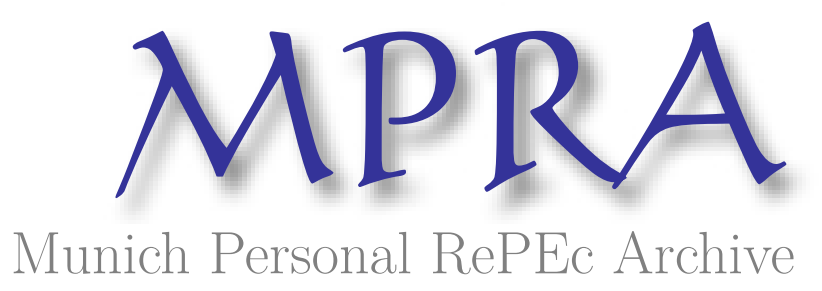

\title{
Planning and Construction of Canop-E Networks for Inclusive, Sustainable Growth in Developing Countries (E.g.- India)
}

Hegadekatti, Kartik

31 March 2017

Online at https://mpra.ub.uni-muenchen.de/82859/

MPRA Paper No. 82859, posted 26 Nov 2017 06:04 UTC 


\section{PLANNING AND CONSTRUCTION OF \\ CANOP-E NETWORKS FOR INCLUSIVE, \\ SUSTAINABLE GROWTH IN DEVELOPING \\ COUNTRIES (E.g.-INDIA)}

\section{Dr.Kartik H \\ Author's email-dr.kartik.h@gmail.com}

\section{ABSTRACT}

In the next few years, India will be the most populous nation on earth. This large population will need a huge increase in agricultural productivity. At the same time, agricultural activity is highly energy and resource intensive. Moreover, many places in India are facing water crisis. Therefore an integrated solution to cultivate food for the people by using water and resources in a sustainable manner is needed.

A Canop-E is a large structure that has integrated harnessing of water, energy and food. I propose an idea to build a network of structures called Canop-E Network which will harness solar and wind power in an integrated manner in developing nations. Additionally it will provide water harvesting facilities also. Using the renewable energy and harvested water, we can grow food. The energy generated can also be used to desalinate water and used in arid areas. At the same time it will also protect the inhabitants of settlements in the structure from rain, sunlight and inclement weather. Thus an integrated solution to food, water and energy security can be obtained. This can be extrapolated to other developing nations.

\section{THE CONCEPT}

A Canop-E unit ${ }^{[1]}$ consists of a huge canopy of 1 Square Kilometre area 500 feet above the ground supported by around a hundred or more evenly spaced heavy load bearing pillars. The Canop-E will have solar panels installed on the outer aspect which will be exposed to the sunshine. The canopy will also be interspersed with small wind turbines to harness wind power that will flow through the canopy in pre-designed gaps. Rain falling on the outer aspect of the canopy will be harvested. It will be led 
through pipes within the supporting pillars and collected below. An entire town can be located below the canopy. Buildings, as high as 30 storeys, can be easily constructed under the canopy.

It is called the Canop-E project (pronounced C-A-N-O-P-Y). 'E' stands for Energy, Environment and Ecology .

The Idea is to take the project further and construct a network of Canop-E units throughout India (and other developing nations) so that the people can benefit from the Energy, Water and Food that can be harvested from such a network

\section{Canop-E}

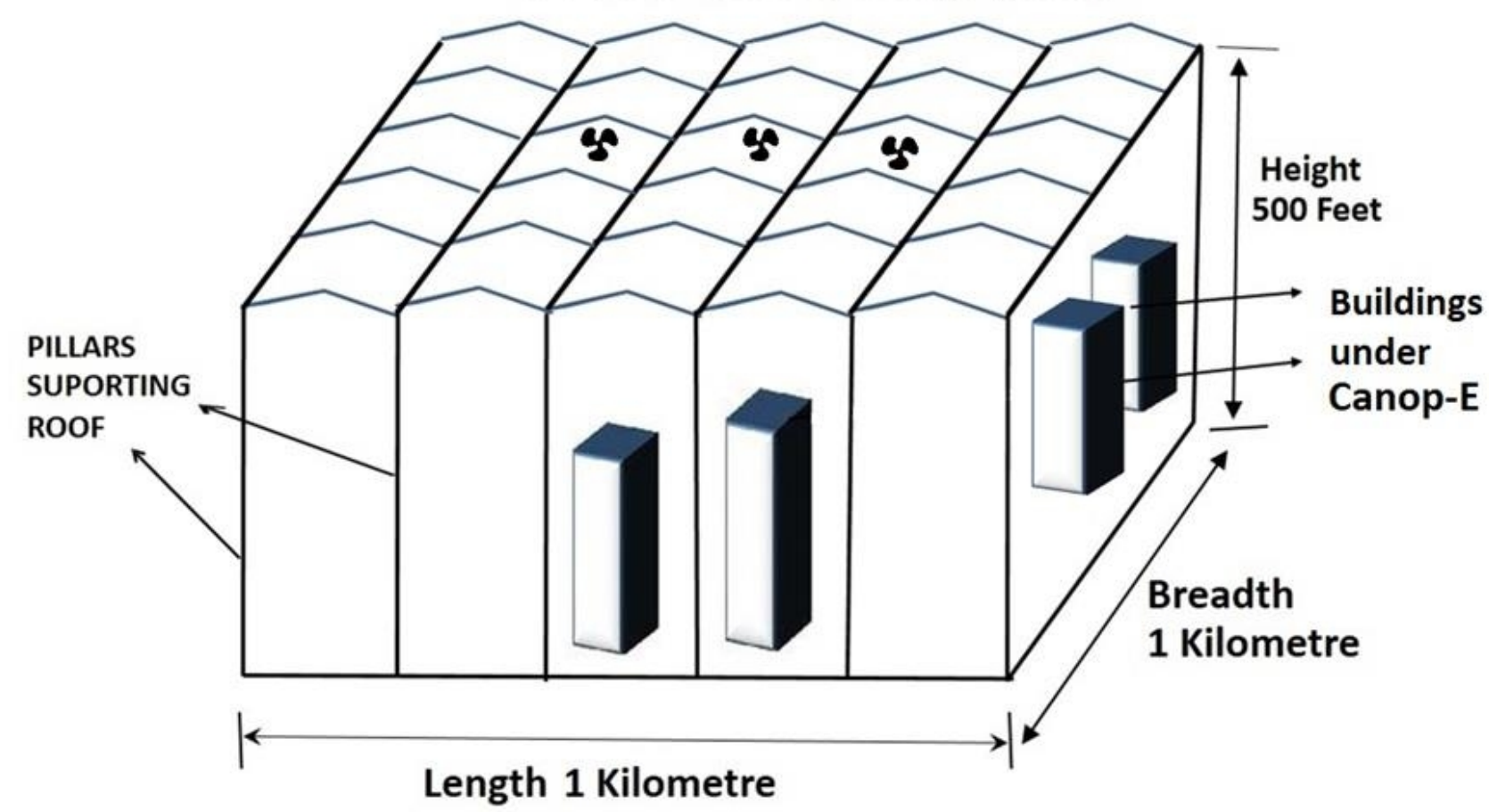

\section{WIND TURBINES FOR ENERGY}

There are several Benefits in building a Canop-E Network. 


\section{ENERGY}

The canopy will cover an area of 1 square kilometer. That is almost 250 acres of area (247 to be exact). It will be about the size of more than 170 football fields. India receives solar energy of between 5 to 6.5 Kilowatt hours per square meter per day (annual average) (refer NREL Image given below).

[Note: US Dollar to Rupee exchange rate used is $\$ 1=65.17$ Indian Rupees -as on 04 April 2017]

The Canop-E will have a collective area of 1 Square Kilometer. That is around 10 Million square feet of floor space. Even at $20 \%$ efficiency of solar panels (which are now being scaled up) calculations show that there is a capacity of 1.1 Gigawatt Hours of solar energy that can be harnessed in this area per day. Depending on the place where it is constructed, this translates to 50 Lakh Rupees worth of power generated/saved $(\$ 76,693)$ per day. That comes to around Rs.180 crores earned/ saved per year (\$27.6 Million).

The material from which the Canop-E will be constructed can be built in panels and assembled on the canopy rooftop. We can use 1 to 2 meters thick polyurethane or hard Polyethylene plates/sheets. They are lightweight and the entire canopy will weigh around 10,000-15,000 tonnes. They can be supported by appropriately spaced and built pillars (either concrete or otherwise) 500 feet tall. Once the Canop-E is built, the wind patterns of the area will put immense stress on the structure. It will be like opening a sheet, 170 football fields large.

The winds will try to blow away the entire Canop-E. But we must view this as an opportunity. Gaps will be provided in certain places for winds to pass through to and from the canopy.

This is like providing openings in the very large sheet that we visualized. Only, the openings will contain small turbines which will rotate as the winds pass through it. These turbines will produce electricity as they rotate. Faster the wind, more the electricity generated. 


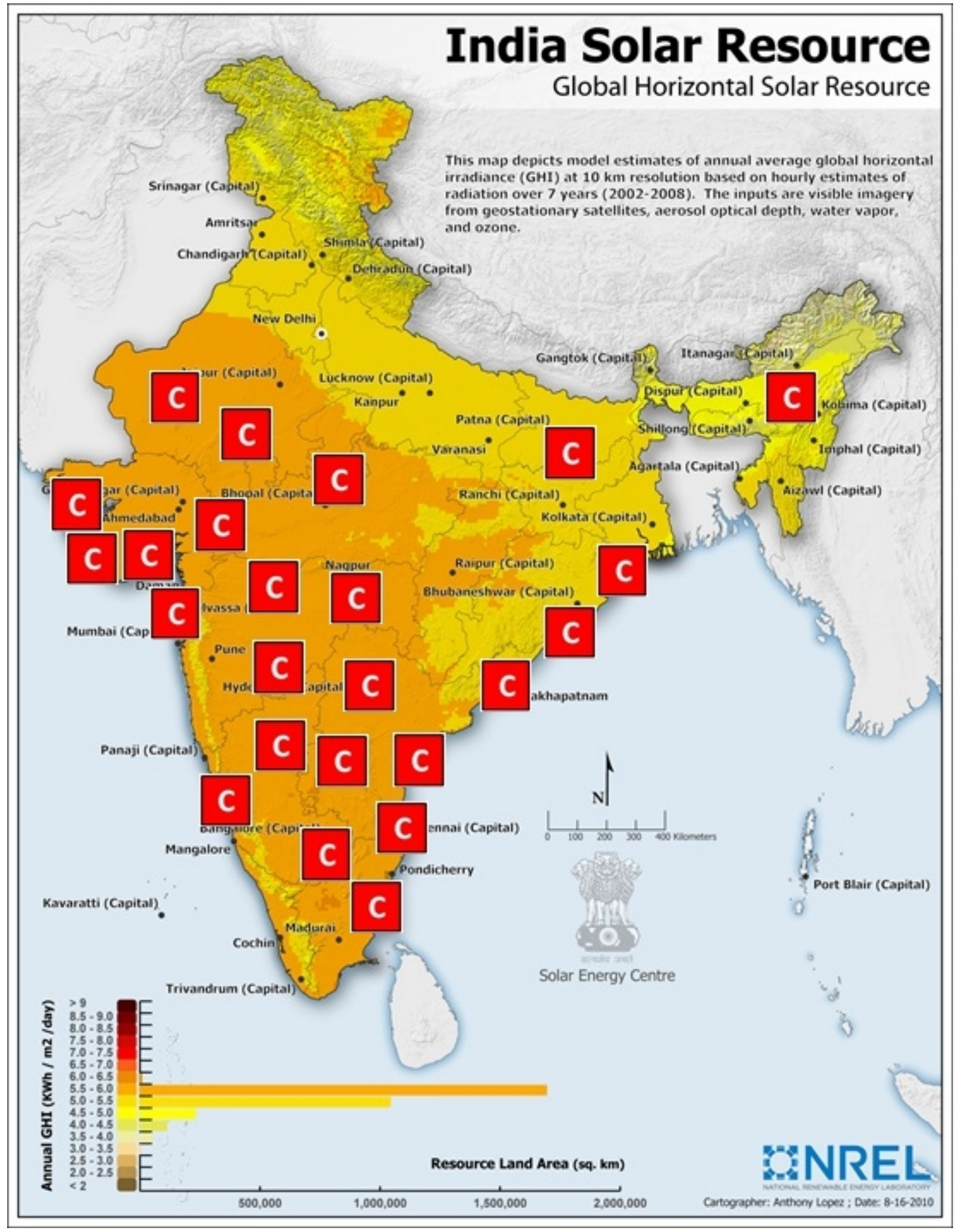

Red squares with ' $\mathrm{C}$ ' (added by the author) indicate at least 2 Canop-E units (not to scale). Map courtesy-NREL (National Renewable Energy Laboratory)

\section{WATER HARVESTING}

The Rain water falling on the Canop-E is funnelled and directed through pipes along the pillars for storage and subsequent use. The average 
rainfall in India is about 30-65 centimeters per year. The canopy can harness this water and will amount to more than 300,000 to 650,000 tons of water harvested every year. This will be enough water for a small town. But the best use of water will be in the hydroponic factories under the Canop-E. Places with more rainfall can harvest more rainwater.

\section{HYDROPONICS}

The Canop-E provides abundant Energy and water from renewable sources in a sustainable manner. As such, the area under the Canop-E is best suited for building Hydroponics using Vertical Farming Systems (VFS). Even if $20 \%$ of the area under the Canop-E is used to build a 15 storey VFS, with a $\$ 3.6$ additional profit per $\mathrm{m}^{-2}$ (compared to Horizontal Hydroponic Systems) with monthly cycles, a yearly profit of \$120 Million can be expected (It may cost around \$35 Million to build the VFS and $\$ 5$ Million to maintain it annually). This will be more than adequate to make the Canop-E self-sufficient in food, water and energy.

\section{DESALINATION}

Each Canop-E unit can produce around 360 GWh of energy in a year. The theoretical absolute minimum amount of energy required by natural osmosis to desalinate average seawater is approximately 1 kilowatt-hour per cubic meter $\left(\mathrm{kwh} / \mathrm{m}^{3}\right)$ i.e per ton of water produced.

Even if half of the energy generated in a Canop-E unit is used for desalination, then 180 Million tonnes of water can be desalinated every year.

Assuming that it needs 20,000 Litres of water per day to irrigate 1 acre of land (this again depends on various factors, but we are assuming an average) ${ }^{[3]}$, almost 25,000 acres can be irrigated. This comes to around $100 \mathrm{Sq}$. Kilometres of irrigated area. This means that 1 Canop-E unit can provide fresh water to irrigate $100 \mathrm{Sq}$. Kilometres of land every year.

Making The Desert Bloom: Canop-E units situated in coastal areas can desalinate the sea water using the energy from the sun. This desalinated water can then be pumped to arid areas nearby or far away through a 
network of pipelines. As discussed above, the desalinated water can be used to irrigate $100 \mathrm{Sq} \mathrm{Km}$ of crop land or more than $500 \mathrm{Sq} . \mathrm{Km}$ of arid area (As we shall not be growing food crops, but raising forests and vegetation, arid areas will need less water to maintain moisture).

\section{CITY PLANNING}

Entire settlements with buildings, schools, parks, roads etc can be housed under the canopy. At an average usage of 25,000 kilowatt hours per year for every inhabitant, the Canopy can easily house a population of more than 10,000 people. Appropriately spaced and sized transparent panels (made of light weight materials) throughout the Canop$\mathrm{E}$ will let in adequate sunlight to the ground below.

Because intense sun rays won't reach the ground, the town under the canopy will be cool and comfortable to live in. Hydroponic units in buildings under the canopy will use the harvested energy and water to grow food for the inhabitants of the Canop-E City.

In fact, the Canop-E will produce surplus food which can earn revenue for the living units that are built under the canopy. Because rain does not reach the ground, people will be protected from inclement weather.

\section{USING PREFABRICATION TECHNOLOGY}

The cost of setting up solar panels will be around Rs.30 per watt (46 cents) ${ }^{[4]}$. That comes to around Rs.1, 500 Crores (\$230 Million). The light plastic roofing along with the support structure will cost Rs.500 Crores (\$76.7 Million). The hundred pillars might cost around Rs.1, 000 Crores (\$153.5 Million) depending on the place, method and materials used in construction.

A total of Rs.3, 000 Crores ( $\$ 460$ Million) may be the cost of building the canopy. But the returns will be obtained in around 3-5 years only considering energy, water and the food harvested by the canopy. Land parcelling and development schemes will further reduce the period of returns.

To reduce the cost of construction, prefabrication technology can be used 
to the maximum. The canopy panels, solar panels, Pillar material, Foundation material, framework superstructure, pipelines etc. can be prefabricated in an assembly line Manner. This will save a lot of labor, transport and material costs and also minimize wastage.

\section{CONCLUSION}

There are several advantages to the Canop-E Network.

1. States with arid regions can set up Canop-E Networks in those places. Remote settlements will be greatly benefited by the Canop-E Networks.

2. A canopy unit will cost around Rs.3,000 Crores ( $\$ 460$ Million). It is estimated that 1,000 Crore rupees ( $\$ 153.5$ Million) in infrastructure investment creates 10,000 to 11,000 jobs $^{[5]}$. Building Canop-E Networks will create several thousand jobs.

3. One Canop-E unit can irrigate 25,000 acres of land, benefitting thousands of farmers. A Canop-E Network can wipe out the water deficit of our major cities and agricultural areas.

4. Renewable energy usage will increase. This will reduce the carbon footprint of the nation that builds Canop-E Networks. Agriculture efficiency will improve as hydroponic units will produce more food in lesser area using renewable energy sources. Since the area under the Canop-E will be cooler in summer (and warmer in winter) than the surroundings. Cooling costs (and also heating costs) like air conditioning and watering is saved.

5. Cool (and warm) comfortable living units- the land under the Canop-E is protected from the vagaries of nature therefore they will be very comfortable places to live in.

6. Due to climate change, and excess use of land, agricultural land is becoming scarce. Excess use of land for agriculture is also a threat to animal habitats and biodiversity. Soil degradation, water scarcity and environmental problems are caused by large-scale open agriculture. VFS units under Canop-E will solve these problems by optimizing resource utilization. 
Canop-E Networks can be built on the outskirts of large cities. Once built, a part of the investment can be recouped by parcelling and selling land under the Canop-E at appropriate prices. People will be free to build their own living units i.e. houses, offices etc. within given specifications. Some areas will be earmarked for hydroponic units (VFS).

The government can move some of its offices to under the Canop-E to encourage habitation. Energy intensive factories can be set up under the canopy. The Canop-E can sell energy during the day and buy it during night-time. This will even out the energy loads on the system.

As India is one of the few large developing nations with a fair amount of resources to build the Canop-E network, it can be implemented in India. Moreover, due to a large population, more people will be benefitted for the same amount of resources spent in a less densely populated region.

Canop-E living units can be set up in any area irrespective of climate or topography. Central Indian Hinterland, coastal areas, Thar Desert, parts of North East, and Peninsular India are ideal places where Canop-E units can provide lot of benefits and ease the life of the people living in that area. Once established, this idea can be extrapolated to other developing nations like African and South American countries to benefit the people of those regions. 


\section{REFERENCES}

[1] Hegadekatti, Kartik, Canop-E: A Sustainable and Inclusive Solution for Modern Living (December 21, 2016). Available at SSRN: https://ssrn.com/abstract=2888383

[2] Touliatos D, Dodd IC, McAinsh M. Vertical farming increases lettuce yield per unit area compared to conventional horizontal hydroponics. Food and Energy Security. 2016;5(3):184-191. doi:10.1002/fes3.83.

[3]https://www.quora.com/How-much-water-does-it-take-to-irrigate-1acre

[4]https://www.bijlibachao.com/solar/solar-panel-cell-cost-price-list-inindia.html

[5] senatorcosta.com/enews/video/2013/SB1Remarks_June5_2013.htm 